\title{
THE ROLE OF HIGHER EDUCATION INSTITUTIONS IN SHAPING STUDENTS' ENTREPRENEURIAL ATTITUDES - CASE STUDIES FROM POLAND AND MALTA
}

\author{
Joanna MACHNIK-SŁOMKA ${ }^{1 *}$, Nicholas BALDACCHINO² \\ ${ }^{1}$ Silesian University of Technology, Faculty of Organization and Management; \\ Joanna.machnik-slomka@polsl.pl, ORCID: 0000-0001-5387-5909 \\ ${ }^{2}$ Malta College Arts Science and Technology, Institute of Engineering and Transport; \\ Nicholas.Baldacchino@mcast.edu.mt, ORCID: 0000-0002-4640-505 \\ * Correspondence author
}

Purpose: Identifying the role or roles of higher education institutions in shaping students' entrepreneurial attitudes, which is the aim of the article which is increasingly becoming topical of great significance for economic development and innovative solutions in industry.

Design/methodology/approach: For the purposes of this research the case study method is based on the selected higher education institutions in Poland and Malta. The method of observation and desk research was also used.

Findings: The results of analyses and studies have confirmed the great importance and possibilities of higher education institutions in shaping entrepreneurial competences of students at different levels of education. They also highlighted the need to place greater emphasis on creating more comprehensive support programs, making wider use of the creation and development of an ecosystem for the development of academic entrepreneurship.

Research limitations/implications: Within the framework of the article, research was conducted on selected examples of higher education institutions in Poland and Malta. The presented results may be of an initial contribution towards future research in different economic and research contexts.

Practical implications: Considerations presented in this article, results of analyses and formulated recommendations can be a valuable source of information especially for higher education institutions and other decision makers dealing with the issue of creating new companies, start-ups established especially on the basis of innovative solutions.

Originality/value: The article emphasized the importance of universities to offer different scenarios as possible for the expansion and development of entrepreneurship. This indicated the role of institutions as crucial in formulating recommendations in the context of shaping entrepreneurial attitudes of students, stressing on the need to develop an entrepreneurship mindset and ecosystem with the co operation of government and private institutions.

Keywords: entrepreneurial attitudes, academic entrepreneurship, academic training.

Category of the paper: research paper. 


\section{Introduction}

Modern market needs and evolution of the cyber era, are continuously changing the dynamics of the socio, economic, and technological scenarios at entrepreneurial levels. The aggressive competition that exists is increasingly encouraging for a more innovative and creative entrepreneurs at academic level to deliver contemporary changes that supports and equips the alumni with the necessary knowledge as future entrepreneurs. It is of particular importance in this context the need to increase and stress for more innovative mindsets in particular regions and countries to foster and adopt entrepreneurial strategies. The world of an entrepreneur is changing at a faster rate that includes the role the abilities to understand the world of networking in modern market mechanisms.

The common problems to shape and foster entrepreneurial attitudes and mindset of current students are addressed in this article focusing on the development of entrepreneurship, particularly when it comes to academic entrepreneurship in education colleges, universities and institutions (Ubulom, 2003; Uwamieye, Aduwa, 2006; Matusiak, K.B., and Matusiak, M., 2007; Banerski et al., 2009; Poznańska, 2014; Kraśnicka et al., 2014; Hayter, 2011; Hvide, Jones, 2018; Łobacz, Głodek, 2018; Cerver et al., 2020; Pasik, 2020). Contemporary entrepreneurial teachings and theories contain the abilities in understanding human or consumer behaviors and attitudes, that are characterized by the readiness to undertake various strategic ventures that will bring changes as per academic studies (Piwowar-Sulej, Kwil, 2018). Thus, students' entrepreneurial studies and attitudes, shapes the engagement in the way they do business and increased knowledge in economic activities, which will be of benefit on the development of academic entrepreneurship (Wyrwa, Sołtysiak, 2016).

One of the significant challenges facing contemporary higher education institutions is the shaping of an appropriate environment and climate for the development of entrepreneurship (Makieła, 2017). This is related to the creation of a new model in higher education institution based that coach's effectiveness and skillful use of knowledge (Wawak, 2017). Academic views on entrepreneurship and tertiary education have been quite different, mainly because of the difficulty to create an acceptable definition. This is so because of different views and research in different economic set ups that are built on different theoretical foundations in various contexts and expertise. Seminal and contemporary researchers opined that academic training in entrepreneurship should prepare students in the business world for a business career (Ubulom, 2003; Uwamieye, Aduwa, 2006).

The aim of the article is to identify the role of universities in shaping and preparing students' entrepreneurial attitudes using selected cases of higher education institutions from Poland and Malta. This paper examines how to effectively educate and shape entrepreneurial attitudes among students to prepare them to operate in modern market mechanisms, to face risks and to be ability to start a business in the future. Recommendations were also presented for higher education institutions in terms of shaping entrepreneurial attitudes and developing students' competences. 


\section{Shaping entrepreneurial attitudes of students - a literature review}

Appropriate entrepreneurial attitudes of students have a great impact on the creation of new jobs, the formation of technology companies, start-ups and thus on the development of entrepreneurship in particular countries. In the literature, many types of entrepreneurships can be distinguished such as organizational entrepreneurship, strategic entrepreneurship, among others (Guth, Ginsberg, 1990; Bratnicki, 2008; Bratnicki, Dyduch, 2003), or technological entrepreneurship, innovative entrepreneurship, and academic entrepreneurship (Stawasz, 2007; Stachowicz, 2015; Machnik-Słomka, Kordel, 2016; Piwowar-Sulej, Kwil, 2018). In general, entrepreneurship can be understood as: an attitude (having, among other things, a direct impact on the entrepreneur's ready to take new actions), a behavior (manifested by the ability to exploit emerging opportunities and ideas) and as a process (referring to the creation of new ventures) (Wyrwa, Sołtysiak, 2016).

The issues discussed in the article are especially related to academic entrepreneurship, which is identified with the activity of higher education institutions (Pasik, 2020) to support the creation of start-ups, spin-offs, spinouts, raising awareness, knowledge, and skills, i.e., shaping entrepreneurial attitudes and competences in entrepreneurship (Banerski et al., 2009). The issue of academic entrepreneurship is more and more often taken up by scientists and practitioners due to its importance and impact on increasing innovation, transfer, and commercialization of technologies (e.g., Matusiak, K.B. and Matusiak, M., 2007; Banerski et al., 2009; Poznańska, 2014; Kraśnicka et al., 2014; Hayter, 2011; Hvide, Jones, 2018; Łobacz, Głodek, 2018; Cerver et al., 2020). Poznańska emphasized that academic entrepreneurship is a specific type of entrepreneurship focused on creative behavior of representatives of the scientific environment and the formation of skills to use the effects of these activities in economic practice (Poznańska, 2014).

Academic entrepreneurship specifically manifests in particular in the orientation towards the use of scientific knowledge in practice, economy, industry where the search for chances, the provision of appropriate resources are important dimensions of the entrepreneurial process (Lobacz, Głodek, 2018). Entrepreneurial attitudes of students of different higher education institutions in the world, which are related to the development of academic entrepreneurship are the subject of research of many authors such as Kraśnicka, Ludvik (2003); Bernat et al. (2008); Wyrwa, Sołtysiak (2016). Already Osuala (1987) stressed that the changes taking place in the world make it necessary for higher education institutions to act as catalysts for the development of entrepreneurship among students of various disciplines through appropriate programs shaping the competencies necessary for the management of start-ups in business. In a broad sense, academic entrepreneurship is in fact related to all activities of the university focused on taking action to support the commercialization of knowledge through various means 
and also on raising knowledge and awareness through an educational offer that considers the practical aspect of education (Poznańska, 2014).

Therefore, it does not focus only on the creation of new companies by students or university employees. Higher education institutions should prepare students from all disciplines, especially technical and related sciences, in terms of industrial experience, ethics, attitudes and in-depth knowledge related to their future occupation in various industrial sectors, whether they are employed or are independent entrepreneurs (Otamiri, 2008).

Entrepreneurs need support at different stages of the entrepreneurial process. The literature usually distinguishes the following stages of development of entrepreneurial activities: pre-incubation (activities until the establishment of the company), incubation (includes support for the newly established company) and acceleration (the last stage of creating a company within which the product offer is subject to market verification) (Piwowar-Sulej, Kwil, 2018). Entrepreneurs, depending on the mentioned stages, need advisory, training, business, promotional, legal support, assistance in raising funds or providing office facilities. Undertaking entrepreneurial activities therefore requires specific competences related to, among other things, establishing and managing a company or developing products (Lobacz, Głodek, 2018). It also requires competencies related to the ability to build relationships with stakeholders and manage these relationships. In the context of contemporary conditions, this is an essential competence that is conducive to developing a company globally and achieving market success. Therefore, it is necessary to provide students, especially those of technical faculties, with appropriate training programs focused on the acquisition of practical skills while ensuring mentoring and coaching also later on the stage of developing a business model (based on an idea or research results) and then creating a company.

The very process of this education, shaping entrepreneurial attitudes of students should be based on cooperation with internal and external structures supporting entrepreneurship and commercialization of knowledge. In the process of learning, it is also necessary to support the higher education institution in developing specialist, scientific knowledge, and skills necessary for developing innovative solutions, conducting research, or preparing a market offer (Lobacz, Głodek, 2018). A carefully designed entrepreneurship curriculum should be based on dialogue with experienced lecturers with baggage of practical experience or with executives from the manufacturing or service sector, so that:

- All students are able to grasp the opportunities by exploring the functions of the world of business and the potential to make careers out of it.

- To assist in developing an intelligent understanding of the modern entrepreneur and the various occupations to be found in the business world and practical ways in understanding the actual functions of the national and international economic systems.

- To prepare students for the eventual future role as an entrepreneur by forming his own business and perform business activities common to many professional areas. 
Modern theoretical and practical entrepreneurship education are two different areas of studies that are in continuous fusion. The demarcation line dividing the theoretical approaches and practical industrial market mechanisms are becoming more and more integrated as a single module. Dutta and Biren (2001) describes it as "brick and mortar" that work with basic tools such as:

- lecturing, mentoring, training, and coaching,

- the use of vocational tertiary education curriculum/techniques,

- creating job/or opportunity for graduates to become self-employed.

This approach has been researched by earlier work of Otamiri (2008) it was posited that modern business education is a fusion of pedagogical entrepreneurial preparation. Akpan (2010) posited that the workable integration of entrepreneurship into the curriculum of the various of fields of study, be it engineering, medicine, social science and business studies is a stem amongst the generation of new business ventures for the present and immediate future of a country's economy. Nowadays, for effective shaping of entrepreneurial attitudes of students, cooperation of higher education institutions with various stakeholders is becoming more and more important. It is important not only to cooperate with enterprises, but also with business environment institutions, especially specialized institutions, such as technology incubators, academic entrepreneurship incubators, science and technology parks, technology and innovation transfer centers and seed capital financial institutions.

Also important in this respect is the cooperation of higher education institutions with representatives of public authorities at various levels. These partners offer a various and wide range of support instruments for shaping and developing entrepreneurial competences of students and also in the scope of creating companies by students, start-ups. We can distinguish different types of support instruments for the development of academic entrepreneurship such as legal instruments (legal regulations, laws, regulations on e.g., intellectual property, commercialization), financial instruments (grants, governmental, regional and EU program, seed capital funds, business angel networks) and so called "soft" instruments related to education and specialized consulting (Borrás, Edquist, 2013). It is also valuable to cooperate with other higher education institutions, institutions of the $R \& D$ sector in order to exchange experiences and strengthen the development of entrepreneurship for the growth of competitiveness and innovation of a given region, country.

Cooperation with different partners in this field is related to the issue of creating and developing an entrepreneurial ecosystem. The importance of these ecosystems for the development of entrepreneurship is emphasized by many authors and researchers for example: Mason, Brown (2014); Hayter et al. (2018); Buła, Schroeder (2020); Bock et al. (2020). Entrepreneurship ecosystem is most often defined as a set of interconnected by different interactions of people, actors creating an enabling environment for entrepreneurship creation and development (Mason, Brown, 2014). Entrepreneurship ecosystems can significantly accelerate the processes of creating startups and commercializing research results. 


\section{Development of student entrepreneurship from the perspective of selected higher education institutions in Poland and Malta}

One of the essential elements of the economic and innovation policy of individual countries should be the activation of cooperation between the science sector and the economy directed at the creation of spin-off, spin-out companies, commercialization of research results by students, employees, and graduates of universities (Poznańska, 2014). Due to the benefits of these activities for increasing competitiveness, human development, the importance of academic entrepreneurship in the global economy is increasing. Therefore, national policy to support this entrepreneurship is important. Due to different social, economic, cultural challenges and conditions, it differs from country to country. In addition, the COVID-19 pandemic has posed new and special challenges for higher education institutions due to a number of barriers and obstacles that have arisen also for the development of entrepreneurship and education in this area. On the other hand, the development of student entrepreneurship may become a remedy for the economic slowdown created by the coronavirus pandemic.

So, the question arises: how to effectively educate and shape entrepreneurial attitudes in this situation? Based on the cooperation undertaken, this article presents examples of selected higher education institutions in Poland and Malta in the field of entrepreneurship education, presenting initiatives and programs devoted to entrepreneurship and shaping entrepreneurial attitudes among students. There are a number of differences between the analyzed countries in terms of economy, social and cultural conditions, development of entrepreneurship as well as a different approach to the education system. However, in both countries, entrepreneurship is part of the teaching program at different levels of education. Many good practices can be cited in these countries in the area of fostering student entrepreneurship. Both Poland and Malta have public and private higher education institutions.

In Poland, the promotion of an entrepreneurial culture and its support is an increasingly important direction included in governmental, regional, and local development programs. A number of governmental and non-governmental organizations, specialized business environment institutions and R\&D institutions in Poland deal with supporting entrepreneurship. At the national level an important role in promoting and developing entrepreneurship and innovativeness is played by the Polish Agency for Enterprise Development (PARP). These institutions implement many projects, programs aimed at the development of entrepreneurship, which allow young entrepreneurs to take advantage of government programs, regional programs (RPO), EU grants, subsidies, loans for creating and developing companies based on innovative ideas. The start-up environment is supported, among others, by the developing network of Academic Incubators of Entrepreneurship (AIP). An important role in this respect is also played by universities, which can provide first-cycle studies (bachelor's or 
engineer's degree), second-cycle studies (master's or engineer's degree) or unified master's studies, as well as doctoral training.

For a small island in the Mediterranean like Malta, job creation remains a consistent challenge for the government. Well paid employment in Malta has been endemic for decades, where in the past entrepreneurship as a subject was more academic oriented reserved only for those who had family history in business and lacked the vocational touch and entrepreneurial values. In response to contemporary challenges, including indications from the EU, the Maltese authorities have taken more intensive measures to support entrepreneurship at the local level in relation to the education system. Universities in Malta play a significant role in this regard. The academic education pathway in Malta consists of several levels: higher vocational education (level 5), bachelor's degree (level 6), master's degree (level 7), doctorate (level 8).

Silesian University of Technology operating in Poland and Malta College Arts Science and Technology (MCAST) were selected to analyze the case studies in the context of shaping entrepreneurial attitudes.

\subsection{Shaping entrepreneurial attitudes of students at the Silesian University of Technology in Gliwice}

The Silesian University of Technology is one of the biggest technical universities in Poland, established in 1945. As the only university in Silesia, the Silesian University of Technology was among 10 Polish universities, laureates of the competition "Initiative of Excellence Research University" of the Ministry of Science and Higher Education (Politechnika Śląska). Science and education at the Silesian University of Technology is conducted in 15 units including 13 faculties and 2 institutes. There are currently over 60 faculties and about 200 specializations with over 18 thousand students (Politechnika Śląska). The University offers first degree studies (engineering and bachelor's), second degree studies - master's, unified master's studies, education at doctoral school and postgraduate studies. Studies are conducted in stationary and non-stationary form. They can be conducted within the framework of the profile: practical and general academic.

Important areas of support at the Silesian University of Technology include (Research University - Education (Uczelnia Badawcza - Kształcenie):

- development of academic entrepreneurship through e.g., specialized trainings conducted by experienced managers and technology brokers,

- assistance in identifying commercialization potential,

- support in establishing and running a company,

- dual education conducted in cooperation with employers (a student takes classes alternately at the University and at a company),

- mentoring involving the student in research activities, project implementation and cooperation with industry. 
At the Silesian University of Technology, activities supporting academic entrepreneurship are realized by particular faculties, institutes, and university units such as: Centre for Incubation and Technology Transfer, Student Career Office and science and technology park "Technopark Gliwice". The Centre for Incubation and Technology Transfer (CITT) of the Silesian University of Technology supports the process of management and commercialization of intellectual property, improving the implementation of research results into practice (Centrum Inkubacji i Transferu Technologii). In this field, the Silesian University of Technology has developed, among others, Regulations for management of intellectual property and a database of the Silesian University of Technology offer in the area of apparatus, laboratories, technologies, and patents. The CITT acquires and realizes many projects financed from external sources, builds, and develops networks for cooperation between science and economy.

The CITT of the Silesian University of Technology is also involved in activities aimed at the development of technological entrepreneurship, which consists mainly in assistance in setting up spinoffs and spinouts. In this respect, CITT implements a pro-quality program in accordance with the Decree of the Rector of the Silesian University of Technology thanks to which it is possible to co-finance the commencement of business activity in the form of spinoff and spin-out companies. The CITT is also supported by providing consultations at the stage of starting companies as well as their further functioning. In the aim of implementation of indirect commercialization, the Special Purpose Company Innovations of the Silesian University of Technology Ltd. was established.

The Student Career Office of the Silesian University of Technology in the field of supporting entrepreneurship meetings in the field of counselling for entrepreneurship, which aim to help to establish business activity, to prepare a business plan (Konkurs Mój Pomysł na Biznes). For many years, the Career Bureau of the Silesian University of Technology has been organizing the competition "My Business Idea", which aims to encourage entrepreneurship among employees, students, and graduates of the Silesian University of Technology. Currently, the 18th edition of the "My Business Idea" competition is already being organized. Ideas based on innovative and sustainable solutions, which can provide new jobs are promoted. Participants in the competition are provided with substantive support in the form of training on creating and managing a company, developing a business plan, innovation and individual consultations with experts. On the basis of the assessment of submitted works, the jury awards prizes in the form of financial for the implementation of ideas, training, internships, or recommendation to locate their startup in business incubators, or technology parks. The Student Career Office of the Silesian University of Technology in connection with the COVID-19 pandemic introduced new services related to the possibility of obtaining advice on psychological, professional and entrepreneurship support (Biuro Karier Studenckich). Moreover, the Student Career Office realizes a lot of programs and projects co-financed by the European Union, concludes a number of agreements on cooperation with companies and other partners, supports the organization of student practice and work placements and organizes study visits to companies for students. 
Many programs promoting academic entrepreneurship have been implemented at the Silesian University of Technology, including (Politechnika Śląska): START - "Programme for the promotion of entrepreneurship in higher education institutions in the Silesian Voivodship" realized from the Human Capital Operational Programme 8.2.1; The program "Creator of Innovation - Support for Innovative Academic Entrepreneurship" realized from the funds of the Ministry of Science and Higher Education; Entrepreneurial Researcher - training and consultancy project implemented under the Human Capital Operational Programme 8.2.1 and Project: "First stage of implementation of the comprehensive development program of the Silesian University of Technology in Gliwice" implemented in the Operational Programme Human Capital 4.1.1.

The Science and Technology Park "TECHNOPARK GLIWICE" Ltd. is in turn a modern business support center, especially for academic entrepreneurship (Technopark Gliwice). It provides infrastructure for startups and mature companies based on cooperation with the Silesian University of Technology, training, and consulting services as well as implementation of international, national, and regional support programs. Technopark Gliwice has extensive cooperation with supporting institutions, universities, science parks, foreign organizations. Technopark carries out many projects financed from various sources. The Technopark has a technological and expert base, is a platform for cooperation between the spheres of science and business (Technopark Gliwice). An important objective of its activities is the transfer of modern technologies to the economy.

Activities aimed at shaping entrepreneurial attitudes of students are also initiated and realized by individual faculties and institutes of the Silesian University of Technology. Classes in subjects related to entrepreneurship are conducted. An example can be the Faculty of Organisation and Management of the Silesian University of Technology (WOIZ) which has realized, in cooperation with external partners such as business environment institutions, enterprises, Zabrze City Hall, Katowice Special Economic Zone (KSSE), many activities for the promotion of pro-innovative culture and shaping entrepreneurial attitudes. In this area, two editions of the Innovator's Day Conference were organized with these partners and students at the Silesian University of Technology. At WOIZ, the Business meets students conference was organized in cooperation with the KSSE Innovator's Club. In 2019, a Conference was organized in the cycle Meetings with Entrepreneurship Edition\#Droga do samorealizacji: dialogue of entrepreneurship with technological entrepreneurship. On the initiative of WOIZ, a Business Advice Point was also established, which provides a platform of support for entrepreneurs and people interested in conducting business.

There are many other initiatives and undertakings aimed at shaping entrepreneurial attitudes of students at the Silesian University of Technology.

Many of them are organized in cooperation with economic and public sector partners. Students at the Silesian University of Technology themselves are involved in the organisation of many events, e.g., as part of Student Scientific Circles. 


\subsection{Examples of academic entrepreneurship support for students at Malta College Arts Science and Technology (MCAST)}

The link that exists between Malta College Arts Science and Technology (MCAST) and Industry including the Maltese Government is maturing along with the new age of world development. MCAST has assumed the role as an agent that collaborates with its links that chains it with industrial needs that modern technology requires. Malta College of Arts, Science and Technology (MCAST) was established in 2001. It is the leading vocational education and training institution in the country. It has 6 institutes and the Gozo Campus. MCAST offers about 180 courses, vocational courses, ranging from certificates to Masters (up to level 7) (MCAST). It also offers the MCAST Professional Research Doctorate (DRes) on the Competitive Behavior of Small Organizations MQF (Level 8) (MCAST Professional Research Doctorate (DRes)).

In 2013, MCAST had to refocus on the topic of entrepreneurship by creating a new directory within its administration, the MCAST Entrepreneurship Centre (MCE). The MCE addresses entrepreneurship for all students in level 4 up to level 6 to elucidate knowledge and skills that will prepare its student population to be more employable and self-reliant for the ever-changing economic technological diversifications that were changing the country. The strategy adopted had the aim to provide MCAST students and alumni alike with the opportunity to transform their creative and innovative ideas across all institutes in level 4 diploma and degree level 6 into a profitable and sustainable business ventures. This approach had two objectives to equip the students with all the necessary knowledge skills and competencies to succeed in the modern and ever-changing entrepreneurial life. Firstly, the focus concentrates on the student's intellective development by designing a curriculum that caters for the levels 4 and 6 in all MCAST institutes, supported by experienced mentors and lecturers with years of industrial experience in entrepreneurship. This is a contributive element in thriving an entrepreneurial mindset which provides the students with the necessary theoretical and practical tenacity in utilizing their abilities and new skills in their future careers. Secondly, the MEC which is an incubator center offers an area related to student findings, helping them to develop their innovative and creative entrepreneurial related activities which serves them to enrich and refine the ideas generated in a more business-oriented environment. The incubation center is not the only assistance that MEC offers but also provides mentors to guide them through in reaching their full potential that reflects modern entrepreneurship ethics and laws and regulatory aspects of the idea generated.

Another contribution by MEC towards its MCAST students is by giving the individual attention the needs and professional advice by offering inhouse and other activities aimed at increasing the entrepreneurial approach vis-à-vis their academic studies. The main forms of entrepreneurial support at MCAST are shown in the table below (Table 1). 
Table 1.

Forms of entrepreneurship support at MCAST

\begin{tabular}{|c|c|c|c|}
\hline $\begin{array}{c}\text { Forms of } \\
\text { entrepreneurship } \\
\text { support/ } \\
\text { Level of Studies }\end{array}$ & Job- Shadowing & Work Placement & Apprenticeship \\
\hline & $\begin{array}{l}\text { This entails the student to } \\
\text { spend a full week 'working' } \\
\text { with the 'Employer' to get } \\
\text { a better understanding of the } \\
\text { work environment. } \\
\text { It is held in the early years } \\
\text { where students have not } \\
\text { decided exactly which } \\
\text { career path to follow. } \\
\text { So, this experience in the } \\
\text { industry will help them } \\
\text { decide which discipline } \\
\text { to follow. } \\
\text { During the job shadowing } \\
\text { as the name implies students } \\
\text { are not expected to } \\
\text { undertake any work but } \\
\text { observe experienced } \\
\text { employees at their } \\
\text { workplace. The emphasis on } \\
\text { this 'work scheme' is for the } \\
\text { student to learn the soft } \\
\text { skills to be able to be ready } \\
\text { for future employment. } \\
\text { (Level } 3.1 \text { ) }\end{array}$ & $\begin{array}{l}\text { The student will be placed } \\
\text { in the industry of their } \\
\text { choice to conduct a hands- } \\
\text { on experience working for } \\
\text { a minimum of } 100 \text { hours and } \\
\text { at the same time still attend } \\
\text { academic classes at MCAST } \\
\text { Campus. } \\
\text { On this scheme the student } \\
\text { is expected to work under } \\
\text { supervision of a trainer and } \\
\text { undertake the same job } \\
\text { responsibilities as a full- } \\
\text { time employee. } \\
\text { Students get the benefit of } \\
\text { experiencing the work } \\
\text { environment and start } \\
\text { working hands-on. It is also } \\
\text { beneficial for their future } \\
\text { employment, to add to their } \\
\text { work portfolio, and CV. }\end{array}$ & $\begin{array}{l}\text { This work experience } \\
\text { scheme is different from } \\
\text { the others as the student } \\
\text { is paid the regular stipend } \\
\text { plus a wage*. } \\
\text { Although still working } \\
\text { under supervision, } \\
\text { as a trainee, the student } \\
\text { will execute the same } \\
\text { work as an 'employee' } \\
\text { (considered as a staff } \\
\text { member) but with less } \\
\text { hours. } \\
\text { There are two types of } \\
\text { 'Apprenticeships', for } \\
\text { level4.2 it is for two days } \\
\text { during the week (and } \\
\text { three days at MCAST) } \\
\text { and full workload during } \\
\text { the summer holidays and } \\
\text { in other cases (Level } 6.3 \text { ) } \\
\text { it's for a full month and } \\
\text { no lessons at MCAST. } \\
\text { (Not all Institutes have } \\
\text { an apprenticeship scheme } \\
\text { for their students). } \\
\text { (Level } 4.2 \text { i Level } 6.3 \text { ) }\end{array}$ \\
\hline
\end{tabular}

Source: own elaboration.

The entrepreneurship program is offered from level 4.2 to 6.3. Payment during the apprenticeship is shared by Jobs Plus (the Maltese Government Employment Agency) and the 'Employer'. In line with international experts Obi, Otamiri (2010) asserted on the actual entrepreneurship syllabus which was adopted by MEC in MCAST database splitting it in two levels i.e., level 4 and level 6:

- Level 4 enables the student to develop a business idea and employability skills that requires the student to turn an idea into a tangible action including the reflection on what makes him more employable. At this level, the emphasis is on the activities by the discovery and exploitation of the innovation in the manufacture and services sector and the lecturer will serve as an empathetic guide by offering suggestions and motivating the learners to self-reflect on what they have learned (MCE, 2019). Practical implementations are not the only part of this strategy, nonetheless the study unit contains the theoretical part by an actionable theory in practice. The main objective at this level is to develop a business idea by helping the student to express the creative ideas in 
developing it into a business proposal. This will instill interest amongst the students to view entrepreneurship not from a start up point of view but rather a complex journey that works on innovative and creative ideas. This strategy will also help students to work in groups, increase self-confidence and resolve conflicts by the ability in weighing risks.

- Level 6 students are helped into being more familiar especially those who had started from level 4 exempted at level 5 but has entered into a new stage in their studies. Apart from learning the main theories of the studies and business startups, an exploration opportunity is created for students to interact and learn from several firsthand situations. In this level students are encouraged to form teams from different classes and different institutes that form part of the University of MCAST. This is an opportunity to work on campus as industry with diverse team members that will help the learners to share entrepreneurial ideas from different perspectives that will generate more creative and feasible solutions. This is also a practical way to interact and to work as realistically as possible in a team by interacting with all stakeholders in industry for the future which is a realistic link with theoretical vocational studies. Experience has shown that students will have to shift out from their comfort zone and explore their entrepreneurial abilities by creating and innovating ideas by being adventurous in risk taking opportunities in their future careers.

MCAST through MEC views entrepreneurial training as a vehicle for lecturing or inculcating necessary entrepreneurial skills to its student population by enabling them to steer their creative imagination into a possible business startup as this is the mission of modern entrepreneurial teachings for vocational and tertiary education students.

\section{Summary}

Higher education institutions face many challenges connected with the need to shape entrepreneurial attitudes responding to market needs, labor market, development of innovativeness and competitiveness of the economy. This article explains the inevitable fusion that entrepreneurship and higher education have become a synergy for dealing with the issue of unemployment, employability, and career development. The results of the conducted analyses of selected higher education institutions from Poland and Malta indicate the use of various approaches and methods for developing entrepreneurial competences of students. This is due to a number of conditions connected with It is a result of many conditions connected, among others, with the realized policy of a given country and the realization of accepted strategies of a given higher education institution, as well as social, cultural, legal, and economic conditions. A characteristic of the both analysed university cases is a complex approach to supporting the development of students' entrepreneurship with the involvement of internal units of the 
university, the use of different forms of entrepreneurship support, i.e. educational programmes, substantive support, specialist consulting, organisation of practices and work placements.

To summarize, based on the literature analysis and the case study analysis, the following recommendations can be formulated for higher education institutions in terms of their role in shaping entrepreneurial attitudes of students:

- Creating comprehensive support programs for students of all majors and disciplines covering different levels of study.

- Creating internal structures (such as incubators, innovation centers, career offices) and entrepreneurship support mechanisms open to other external structures, networks, systems.

- Shaping effective network relations with different stakeholders towards creating an entrepreneurship ecosystem.

- Using various methods and tools, such as comprehensive educational programs, lectures, trainings, conferences, workshops, coaching, mentoring, organizing internships, simulation educational games, competitions, implementing and promoting national and international programs, joining thematic networks, developing cooperation platforms, support in creating companies by students and graduates, scientific circles, grants, scholarships, etc.

- Create a good practice database and promote it locally, nationally, and internationally.

- Using various means of communication, including social media in an innovative and attractive way.

- Bringing students closer to the attitudes of enterprising managers, successful people, e.g., through the organisation of study visits to enterprises, the possibility of interviews, meetings and talks with business practitioners at universities.

- Strengthening the cooperation of universities with the business community, taking care of mutual benefits, e.g., by supporting entrepreneurs in the field of counselling, educational services, assistance in seeking sources of financing projects, opening consultation points in various areas.

The effective shaping of students' entrepreneurial attitudes will allow us to face the everchanging needs of the market by providing highly qualified graduates with creative initiative, the ability to take risks and the courage to start a business. 


\section{References}

1. Akpan, A. (2010). NYSC boss decries sagging unemployment in Nigeria. Lagos: The Guardian Newspaper.

2. Banerski, G., Gryzik, A., Matusiak, K.B., Mażewska, M., Stawasz, E. (2009). Przedsiębiorczość akademicka (rozwój firm spin-off, spin-out) - zapotrzebowanie na szkolenia stużace jej rozwojowi. Raport z badań. Warszawa: Polska Agencja Rozwoju Przedsiębiorczości.

3. Bernat, T., Kordysa, J., Kunasz, M. (2008). Przedsiębiorczość studentów w wybranych krajach Europy Środkowo-Wschodniej. Szczecin: Wydawnictwo PRINT GROUP.

4. Biuro Karier Studenckich. Available online http://www.kariera.polsl.pl/, 27.07.2021.

5. Bock, C., Dilmetz, D.S., et al. (2020). How the university ecosystem shapes the innovation capacities of undergraduate students - evidence from Germany. Industry and Innovation, vol. 27, pp. 16-24.

6. Borrás, S., Edquist, C. (2013). The Choice of Innovation Policy Instruments, Centre for Innovation, Research and Competence in the Learning Economy (CIRCLE). Lund: Lund University.

7. Bratnicki, M. (2008). Konfiguracyjne ujęcie przedsiębiorczości organizacyjnej. Ekonomika i Organizacja Przedsiębiorstwa, Vol. 6, pp. 17-22.

8. Bratnicki, M., Dyduch, W. (2003). Entrepreneurship Strategies and Social Capital in Polish Organizations. Baltimore.

9. Buła, P., Schroeder, T. (2020). Wybrane aspekty koewolucji polskiego ekosystemu przedsiębiorczości, Przegląd Organizacji, Vol. 10, pp. 20-27.

10. Centrum Inkubacji i Transferu Technologii. Available online https://www.polsl.pl/rjo4citt/, 27.07.2021.

11. Cerver, Romero, E., Ferreira, J., Fernandes, C. (2020). The multiple faces of the entrepreneurial university: a review of the prevailing theoretical approaches. The Journal of Technology Transfer, vol. 45, pp. 22-28.

12. Dutta, S., Biren, B. (2001). Business formation on the Internet, results from the year 2000 study. European Management Journal, Vol 19, No. 2, pp. 449-62.

13. Guth, W.D., Ginsberg, A. (1990). Corporate Entrepreneurship. Strategic Management Journal, Vol. 11.

14. Hayter, C. (2011). In search of the profit-maximizing actor: Motivations and definitions of success from nascent academic entrepreneurs. The Journal of Technology Transfer, vol. 36, pp. 347-352.

15. Hayter, C., Nelson, A., Zayed, S., et. al., (2018). Conceptualizing academic entrepreneurship ecosystems: a review, analysis, and extension of the literature. The Journal of Technology Transfer, vol. 43, pp. 4-7. 
16. Hvide, H., Jones, B. (2018). University Innovation and the Professor's Privilege. American Economic Review, vol. 108, pp. 1860-1876.

17. Konkurs Mój Pomyst na Biznes. Available online http://www.kariera.polsl.pl/ konkurs/konkurs.ht, 27.07.2021.

18. Kraśnicka, T., Głód, G., Ludvik, L., Peterkova, J. (2014). Uwarunkowania intencji przedsiębiorczych studentów uczelni ekonomicznych Polski i Czech. Przedsiębiorczość Edukacja, no. 10, p. 316.

19. Kraśnicka, T., Ludvik, L. (2003). Poglądy studentów w kwestii przedsiębiorczości w kontekście integracji europejskiej. In: H. Bieniok (Ed.), Przedsiębiorczość, konkurencyjność oraz kondycja matych i średnich przedsiębiorstw $w$ obliczu integracji z Unia Europejska. Katowice: Wydawnictwo AE.

20. Łobacz, K., Głodek, P. (2018). Przedsiębiorczość akademicka jako czynnik rozwoju kapitału ludzkiego. Horyzonty Wychowania, vol. 17(44), pp. 167-177.

21. Machnik-Słomka, J., Kordel, P. (2016). Significance of technological entrepreneurship and creativity in metallurgical enterprises. Metalurgija, vol. 55. iss. 4, pp. 855-858.

22. Makieła, Z. (2017). Przedsiębiorczość i innowacyjność akademicka w Polsce. Przedsiębiorczość - Edukacja, vol. 13.

23. Mason, P.C., Brown, D.R. (2014). Entrepreneurial Ecosystems and Growth Oriented Entrepreneurship. Program OECD LEED.

24. Matusiak, K.B., Matusiak, M. (2007). Pojęcie i ekonomiczne znaczenie przedsiębiorczości akademickiej. Zeszyty Naukowe Uniwersytetu Szczecińskiego, Ekonomiczne Problemy Ustug, vol. 453, pp. 158-163.

25. MCAST Entrepreneurship Centre. Available online https://www.maltaenterprise.com/ mcast-entrepreneurship-centre-set-kbic, 31.07.2019.

26. MCAST. Available online https://www.mcast.edu.mt/about-mcast/, 25.07.2021.

27. MCASTProfessional Research Doctorate (DRes). Available online https://www.mcast.edu.mt/wp-content/uploads/Professional-Research-Doctorate_V2.pdf, 25.07.2021.

28. Obi, E.C., Otamiri, S. (2010). Information and Communication Technology in Business Education: Challenges and the way forward. Journal of Management and Enterprise Development. Vol. 7, No. 4.

29. Osuala, E.C. (1987). Business Education: Principles and Practice. Onitsha: Africana Fep. Publishing Co.

30. Otamiri, S. (2008). Business Education and self-employment: A Case for Entrepreneurship Education. Business Education Journal.

31. Pasik, M. (2020). Przedsiębiorczość akademicka w świetle badań literatury. In: M. Ćwiklicki, A. Frączkiewicz-Wronka, A. Pacut, K. Sienkiewicz-Małyjurek (Eds.), Współczesne problemy zarządzania publicznego i przedsiębiorczości społecznej (pp.148- 
165). Kraków: Małopolska Szkoła Administracji Publicznej Uniwersytetu Ekonomicznego w Krakowie.

32. Piwowar-Sulej, K., Kwil, I. (2018). Przedsiębiorczość, przedsiębiorczość akademicka i technologiczna, innowacyjność - próba systematyzacji. Przegląd Organizacji, No. 7(942), pp. 18-24.

33. Politechnika Śląska. Available online https://www.polsl.pl/uczelnia/o-uczelni, 26.07.2021.

34. Poznańska, K. (2014). Przedsiębiorczość akademicka: cechy i znaczenie w gospodarce światowej i polskiej. Studia Ekonomiczne/Uniwersytet Ekonomiczny w Katowicach, $n r$ 183, Innowacyjność współczesnych organizacji. Cz. 2, Kierunki i wyniki badań, pp.164-172.

35. Stachowicz, J. (2015). Przedsiębiorczość technologiczna kluczową siłą rozwoju przedsiębiorstw wysokich technologii. Zeszyty Naukowe Politechniki Śląskiej, Organizacja i Zarzadzanie, Z. 83, No. 1941, pp. 629-637.

36. Stawasz, E. (2007). Stymulowanie przedsiębiorczości środowiska naukowego w Polsce. Zeszyty Naukowe Uniwersytetu Szczecińskiego, no. 453, pp. 265-276.

37. Technopark Gliwice. Available online http://technopark.gliwice.pl/o-nas/, 27.07.2021.

38. Ubulom, W.J. (2003). An Evaluation of Undergraduate Business Education Programme of tertiary institutions in Rivers State. Business Education Journal, Vol. 4, No. 1.

39. Uczelnia Badawcza - Kształcenie. Available online https://www.polsl.pl/rjo3-ks/uczelniabadawcza-ksztalcenie/, 26.07.2021.

40. Uwamieye, R., Aduwa-Ogiegbean, S.E. (2006). Developing Entrepreneurship Culture among young people in Nigeria. Journal of curriculum studies (CON), vol. 13, No. 3.

41. Wawak, T. (2017). Zarzadzanie w szkołach wyższych i innowacje w gospodarce. Kraków: Wydawnictwo Uniwersytetu Jagiellońskiego.

42. Wyrwa, D., Sołtysiak M. (2016). Przedsiębiorczość akademicka - postawy przedsiębiorcze studentów. Zeszyty Naukowe PWSZ w Płocku, Nauki Ekonomiczne, t. XXIV. 